\section{KAJIAN ETIKA, ETIS DAN ESTETIKA DALAM KARYA SENI RUPA}

Joko Maruto

Fakultas Bahasa dan Seni, Universitas Negeri Yogyakarta

email : joko_maruto@uny.ac.id

\section{Abstrak}

Penelitian ini bertujuan mendeskripsikan karya seni rupa menyangkut garis, warna, bentuk, dan komposisi yang memenuhi kriteria etika, etis, dan estetika. Metode yang digunakan adalah deskriptif kualitatif. Sumber data berupa lukisan dan patung yang dipilih secara proporsional dan purpossive sampling. Analisa data dilakukan proses ini ada tiga hal utama yaitu reduksi data, penyajian data, dan penarikan kesimpulan/verifikasi sebagai suatu yang jalin-menjalin pada saat sebelum, selama dan sesudah pengumpulan data berlangsung. Hasil penelitian sebagai berikut: (1) garis lebih berperan sebagai pembentuk kontur objek (outline) dan juga pembentuk orang, bangunan, pohon, awan, serta gunung. Dalam hal ini, garis menjadi sarana pengungkapan ide, suasana, dan kesan; (2) warna yang digunakan cenderung warna campuran, misalnya primer dan sekunder untuk memberi kesan kematangan melalui warna-warna, seperti merah, kuning, hijau, ungu, dan oranye; (3) bentuk gambar cenderung menampilkan figur manusia secara realis; (4) komposisi cenderung menampilkan pusat perhatian sehingga objek dapat terfokus; (5) karya yang memenuhi kriteria etika, etis, dan estetika, terutama karya rupa yang ada unsur erotisme atau nude, bergantung pada teks, konteks, serta kegunaannya.

Kata kunci:etika, etis, estetika karya seni rupa

\section{THE STUDY OF ETHICS, ETHICAL VALUES, AND AESTHETICS IN THE WORKS OF FINE ARTS}

\section{Abstract}

This research is to describe a work of art in terms of lines, colors, shapes and compositions fulfilling the criteria of ethics, ethical values, and aesthetics. The method used in this research is qualititative-descriptive method, while the sources of data are paintings and sculptures proportionally chosen in a kind of purpossive sampling. The data analysis was conducted through data reduction, data serving, and data concluding which are continuously conducted before, at the time of, and after the data collection. The results of this research show that (1) lines play more important roles in shaping the picture of human figures, buildings, trees, clouds, and mountains. In this case, lines are used to express ideas, atmosphere, and impression; (2) the colors used in these works of art tend to be mixed colors such as primary and secondary colors to give the impression of maturity through the colors of red, yellow, green, purple, and orange; (3) the shapes of the pictures tend to describe human figures in the ways used in realism; (4) the compositions tend to show the center of interest so that the objects can be more focused; and (5) the works fulfilling the criteria of ethics, ethical values, and asthethics, especially the works having the elements of nudism and erotism, depend on the text, context, and functions.

Key words: ethics, ethical values, aesthetics, fine arts

\section{PENDAHULUAN}

Mencermati karya-karya para seniman yang tersebar di masyarakat, baik karya musik, drama, tari, dan seni rupa. Kemajuan teknologi komonikasi, seperti media cetak dan elektronik, membuat dunia semakin sempit. Globalisasi sudah dirasakan. Kejadian yang terjadi di belahan bumi yang jauh dapat dinikmati dan disaksikan dalam waktu bersamaan. Pengaruh globalisasi membawa dampak positif dan baik dalam kehidupan politik dan budaya.

Seni adalah ungkapan perasaan yang merupakan kristalisasi ide-ide yang bersumber dari pengalaman imajinatif. Ia merupakan respon atas pengamatan dan penjelajahan terhadap kehidupan masyarakat, seperti agama, budaya, figuristiadat, dan lingkungan alam. Setelah itu, melalui dorongan internal muncullah getaran-getaran intuitif yang merangsang emosi dan imajinasi untuk diekspresikan ke dalam karya seni.

Dalam menciptakan karya seni, seniman tidak bisa lepas dari pengaruh lingkungan, seperti agama, figur-istiadat, dan budaya. Oleh sebab itu, setiap karya seni akan mencerminkan latar belakang nilai-nilai budaya masyarakatnya dan merupakan kenyataan yang langsung dihadapi sebagai rangsangan atau pemicu kreativitas kesenimanannya (Sumardjo, 2000: 233).

Dalam seni rupa pengaruh lingkungan dan dampak dari globalisasi sangat dirasa. Para seniman lukis, patung, dan lainnya dengan bebas mengekpresikan ideide lewat karyanya. Munculnya suatu karya seni tentu mengalami proses yang panjang. Setiap karya seni yang diciptakan oleh seorang seniman pada hakikatnya merupakan suatu karakteristik. Karakteristik yang terdapat dalam suatu karya seni sekaligus menjadi refleksi identitas pribadi penciptanya. Identitas pribadi yang terdapat dalam suatu karya seni pada dasarnya merupakan hasil pemikiran yang dipadukan dengan citarasa dan pengalaman estetik seniman serta dimanifestasikan kedalam media ekspresi, dengan kemampuan teknik yang ada padanya. Kemampuan menuangkan ide kedalam media ekpresi antara seniman yang satu dengan seniman yang lain tentu berbeda. Masing-masing mempunyai kemampuan 
dan karakter tersendiri. Kebinekaan karya tersebut sebenarnya menambah khasanah kesenirupaan.

Kebebasan seniman berkarya kadang kala menimbulkan pro dan kontra di masyarakat. Hal tersebut sudah biasa terjadi dan wajar, sebab masyarakat terdiri dari banyak lapisan, golongan, serta tingkat pendidikan yangjuga beragam. Misalnya,pada tahun delapan puluhan ketika sekelompok seniman muda mendobrak tatanan kesenirupaan Indonesia dengan menamakan diri "Seni Rupa Baru", karya yang ditampilkan sangat beragam. Salah satu diantaranya adalah karya lukis yang menggambarkan figur Ken Dedes berparas cantik, memakai celana jin dengan resleting bagian depan terbuka, dan bertelanjang dada, seperti dalam karya Dede Supria. Penampilan karya seniman muda tersebut sempat menjadi polemik karena dianggap tidak sopan dan merusak moral. Hal itu wajar karena yang menilai berasal dari komponen masyarakat dengan latar belakang pengetahuan dan pendidikan beragam.

Di Program Seni Rupa, baru-baru ini, dikejutkan oleh karya sekelompok mahasiswa yang membuat patung wanita telanjang bulat dipajang ditempat terbuka, sehingga sempat menjadi polemik di kalangan mahasiswa dan dosen. Oleh karena penempatannya dikampus dilihat oleh mahasiswa dan masyaraka umum. Karena polemik itulah maka bagian-bagian yang dianggap terlarang ditutupi dengan menempelkan semen, sehingga kalau ditinjau dari segi estetis, patung yang sudah ditutupi bagian-bagian terlarang tersebut sangat mengganggu dan mengurangi keindahan, karena patung tersebut dirancang memang telanjang bulat.

Dunia seni musik juga dihebohkan dengan goyang ngebornya Inul. Sempat juga terjadi pro dan kontra dikalangan pengamat, ada yang setuju dan tidak, ada yang mencekal dan tidak. Banyak lagi contoh-contoh hasil karya seni dalam masyarakat yang menimbulkan pro dan kontra. Permasalahan tersebut menjadi latar belakang penulis untuk meneliti tentang karya seni rupa dengan kajian "Etika, Etis, dan Estetika" Penelitian ini ditujukan untuk mengkaji dan mendiskripsikan unsur rupa dalam karya seni rupa dan mengkaji dan mendeskripsikan seni rupa yang memenuhi kriteria etika, etis, dan estetika.

\section{METODE PENELITIAN}

Metode yang digunakan dalam penelitian ini adalah deskriptif kualitatif Pengumpulan data menggunakan snow ballsampling dan figure sampling. Data yang diperoleh dari informan satu ke informan lain, seperti bola salju yang menggelinding, makin lama makin berkembang. Sementara itu, untuk menentukan data, terutama dalam menentukan karya sebagai figure analisis, digunakan proportional sampling. Penelitian ini mengambil beberapa lukisan yang sudah diketahui sifat-sifat sebelumnya.
Pengumpulan data peneliti dilakukan melalui pengamatan langsung terhadap beberapa objek penelitian, observasi dan dokumentasi dengan pemotretan, wawancara, dan pencatatan. Pencatatan menggunakan peralatan tulis dan blocknote digunakan untuk mencatat semua informasi yang diperoleh dalam setiap melakukan kegiatan penelitian, juga menggunakan analisis dokumen dari foto-foto karya yang berhubungan dengan tujuannya adalah untuk mendapatkan data sebanyak-banyaknya yang akurat.

\section{TINJAUAN PUSTAKA}

Etika

Etika merupakan bentuk pengendalian diri dalam pergaulan hidup bersama. Manusia adalah homo sosius, makhluk berteman. Ia tidak dapat hidup sendirian. Ia selalu bersama-sama dengan orang lain. Manusia hanya dapat hidup dengan sebaik-baiknya dan hanya akan mempunyai arti apabila dapat hidup bersama-sama di dalam masyarakat. Tidak dapat dibayangkan adanya manusia yang hidup menyendiri tanpa berhubungan dan bergaul dengan manusia lain. Hanya dengan hidup bersama manusia dapat berkembang dengan wajar. Hal ini menunjukkan bahwa manusia memerlukan bantuan orang lain untuk kesempurnaan hidupnya.

Bantuan tersebut tidak hanya untuk memenuhi kebutuhan jasmani, tetapi juga kebutuhan rohani. Manusia sangat memerlukan pengertian, kasih sayang, harga diri, pengakuan, dan tanggapan-tanggapan emosional yang sangat penting bagi pergaulan dan kelangsungan hidup yang sehat. Semua hal tersebut merupakan kebutuhan rohani yang hanya dapat diperoleh dalam hubungannya dengan manusia lain di tengah masyarakat. Inilah kodrat manusia sebagai makhluk sosial karena ternyata manusia baru dapat disebut manusia dalam hubungannya dengan orang lain, bukan dalam kesendiriannya.

Dalam kehidupan bersama orang harus mengatur dirinya. Tidak ada seorangpun dapat berbuat sekehendak hatinya. Ia harus menyesuaikan diri dengan lingkungan, tunduk kepada aturan bertingkah laku yang berlaku. Dengan demikian, orang hanya bebas berbuat dalam aturan tingkah laku yang baik. Peraturan untuk bertingkah laku yang baik disebut tata susila atau etika. Dalam tujuan etika ini maka orang dinilai dari tingkah laku, mana yang dapat dinilai baik dan mana yang jahat (Sura, $1985: 38$ ).

Etis

Etis berasal dari ethics yang berarti ilmu pengetahuan tentang asas-asas akhlak; etika hal tingkah laku dan kesusilaan: Etis dihubungkan dengan kebiasaan yang berlaku dilingkungan komunitas yang sudah menjadi kesepakatankesepakatan, baik tertulis maupun tidak tertulis. Kebiasaan-kebiasaan tersebut 
menjadi tradisi dan adat istiadat, misalnya kebiasaan orang barat dan timur sanga berbeda. Orang barat lebih cenderung bebas dalam segala hal, baik masalah pergaulan, pakaian, maupun kesenian.

\section{Estetika}

Estetika merupakan cabang filsafat yang menelaah dan membahas seni, keindahan, serta tanggapan manusia terhadapnya. Estetika dikenal memiliki dua pendekatan. Pertama, langsung meneliti objek-objek, benda-benda, alam indah, serta karya seni. Kedua, menyoroti situasi kontemplasi rasa indah yang sedang dialami subjek, yang kemudian melahirkan pengalaman estetika. Persoalan estetika ini kemudian melahirkan berbagai pengertian yang sangat variatif, dalam arti memiliki banyak perspektif pendekatan, sehingga persoalan estetika bergantung pada situasi, kondisi, dan posisinya berada.

\section{Penciptaan Karya Sen}

Pengungkapan karya seni pada tataran akademis, hendaknya didasari oleh deskripsi pemikiran yang terstruktur dan sedapat mungkin menggambarkan suatu proses yang rinci, mengacu pada etika, etis, dan estetika. Sehubungan dengan permasalahan di atas, yang dijadikan sebagai landasan dalam penciptaan karya seni adalah dorongan emosi dan kesadaran untuk mewujudkan harmoni yang berawal dari pengalaman pribadi yang berbeda-beda. Dengan menelusuri dan mengkaji nilai-nilai tersebut, dorongan intuitif yang bersifat imajinatif untuk diwujudkan ke dalam karya seni rupa dapat diberikan.

Melalui perenungan dan penghayatan terhadap gejala yang ada, muncu suatu gagasan tentang esensi dualistis dalam tataran kehidupan bermasyaraka yang substansinya merupakan satu kesatuan yang bersinergi, berdasar atas potensi yang dimiliki. Fenomena kehidupan saat ini cenderung mencerminkan ketimpangan-ketimpangan yang terjadi dan mengarah pada disharmoni yang mengakibatkan terjadinya berbagai konflik dalam masyarakat. Pandangan yang berorientasi pada dominasi materialistis berimplikasi terhadap merosotnya moral manusia, sehingga terjadi diskriminasi, pelecehan, penurunan hak dan martaba manusia, baik secara individu, kelompok maupun golongan. Oleh karena itu, penciptaan seni didasari dengan etika, etis dan estetika

Adapun yang dimaksud nilai dalam hal ini adalah sesuatu yang dipandang berharga oleh orang atau kelompok orang, serta dijadikan acuan tindakan maupun pengarti arah hidup. Nilai tersebut ditumbuhkan dan dibatinkan dalam kebudayaan orang itu, yang dihayati sebagai jagat makna hidup, diwacanakan, serta dihayati dalam bahasa jagat.

Kata figur (dalam bahasa Inggris symbol) mengandung arti 'untuk sesuatu' atau juga 'menggambarkan sesuatu', khususnya untuk menggambarkan sesuatu yang immaterial, abstrak, suatu ide, kualitas, tanda-tanda suatu obyek, proses, dan lain-lain. Dalam hal ini penggunaan figur dalam suatu karya seni memiliki arti yang sangat penting karena tidak semua pengalaman manusia dapat dijabarkan secara verbal dan terinci. Oleh sebab itu, manusia manciptakan tanda atau figur sebagai media komunikasi.

Sehubungan dengan karya seni yang diciptakan, pengalaman batin ditransformasikan ke dalam karya visual, sebagai suatu pencitraan terhadap nilainilai yang penuh makna, serta melalui abstraksi dan aktualisasi, sehingga tercipta karya-karya seni yang bernuansa simbolik dalam menerjemahkan ide-ide yang bersumber pada kehidupan figur.

\section{Seni Rupa}

Seni rupa adalah seni yang terjadi karena visual (wujud). Kalau tidak terwujud bukan seni rupa. Wujud nyata itulah yang dinamakan seni rupa. Beberapa definisi seni dengan batasan-batasannya yang beraneka ragam dan cara pandang serta penafsiran yang berbeda-beda telah banyak disampaikan banyak ahli. Seni memiliki cakupan yang sangat luas dan memiliki fase yang bermacam-macam, seperti cerita orang buta yang ingin melihat gajah. Banyak pakar dari disiplin ilmu berbeda yang berusaha memberikan definisi tentang seni. Namun, karena seni memiliki cakupan yang luas,akibatnya seni memiliki arti jamak. Soedarso (1990: 1) menyatakan bahwa seni adalah segala macam keindahan yang diciptakan oleh manusia. Oleh karena itu, menurut jalan pikiran ini, seni merupakan produk keindahan, suatu usaha manusia untuk menciptakan yang indah-indah, yang dapat mendatangkan kenikmatan.

Seni merupakan kegiatan rohani manusia yang merefleksikan realitas dalam suatu karya yang karena bentuk dan isinya mempunyai daya untuk membangkitkan pengalaman tertentu dalam alam rohani penerimanya. Dalam definisi ini dengan tegas dijelaskan bahwa seni merupakan kegiatan rohani, dan bukan semata-mata kegiatan jasmani. Keutuhan karya seni sangat ditentukan oleh keterlibatan rohani senimannya dalam berkarya, yang dapat menggetarkan cita rasa, baik si pencipta maupun penikmatnya.

Sementara itu, Thomas Munro (Soedarso, 1990. 3-5) berpandangan bahwa seni adalah alat buatan manusia untuk menimbulkan efek-efek psikologis atas manusia lain yang melihatnya. Efek tersebut mencakup tanggapan-tanggapan yang berwujud pengamatan, pengenalan, dan imajinasi yang rasional maupun yang emosional. Pandangan ini menekankan kegiatan rohani di pihak penerima. Seni harus ditanggapi dengan serius dan dengan segenap fungsi jiwa yang ada.

Atas dasar pemikiran ini, seandainya seni dan indah harus menempatkan diri pada posisinya masing-masing dalam menyatakan keberadaan suatu karya 
atau benda seni, hal ini memunculkan pernyataan, apakah yang dimaksud dengan indah atau keindahan itu, dan bagaimanakah bentuk serta wujudnya?

Mengacu kepada fenomena dan realitas keindahan yang ada, serta terlepas dari subjektivitas yang dimiliki, Djelantik (1985: 1) menggolongkan definis keindahan menjadi dua, yaitu keindahan alami atau keindahan yang tidak dibuat oleh manusia dan keindahan yang diciptakan atau diwujudkan manusia. Barangbarang buatan manusia, secara umum, merupakan barang kesenian. Pemikiran tersebut menegaskan bahwa keindahan memiliki figur atau sifat alamiah. Keindahan yang berkaitan dengan ciptaan manusia digolongkan dalam karya seni sebagai ciptaan kreatif berdasarkan keahliannya.

Dari sudut pandang lain, seni dianggap sebagai kemahiran seseorang dalam mengungkapkan perasaan. Hasil dari kegiatan ini harus merupakan suatu keutuhan dan kebulatan organis, antara figur yang satu dengan yang lainnya, sehingga mencapai kesatuan. Dalam hal ini, Gie (1976: 18-20) menjelaskan bahwa seni dan hasil karya seni haruslah merupakan suatu kebulatan yang bersifa organis. Setiap bagian memainkan peranan yang tidak hanya dalam rangka dirinya sendiri, melainkan juga dalam rangka semua bagian lainnya. Tidak ada bagian yang dapat berdiri sendiri, melainkan harus bersama-sama bagian lainnya yang membentuk kesatuan organis.

Pandangan-pandangan tentang seni di atas terlihat berbeda satu dengan lainnya, tergantung latar belakang para tokoh yang menyampaikan. Namun terdapat titik temu yang dapat dijadikan pegangan, yaitu bahwa seni lebih dekat dengan rasa atau perasaan. Karena rasa dimiliki semua orang, senipun dapat dinikmati semua orang.

Karya seni rupa dapat ditinjau dari dua sisi, yaitu dari sisi bentuk dan isi Sisi bentuk merupakan wujud rupa atau inderawi yang dapat diamati melalui unsur rupanya, seperti : garis, warna, tekstur, gelap terang dan volume. Sementara itu, sisi isi merupakan pranata ruhaniyah (ide) dari berbagai gambaran perasaan dan digambarkan dalam wujud lahiriah (subject matter).

Karya seni sebagai satu kesatuan organik (organic unity) antar unsurunsurnya. Bentuk dan isi harus sama-sama dilihat sebagai kesatuan organis, bukan sebagai sistem mekanik. Pada sistem organik, setiap unsur-unsur tidak berperan sendiri-sendiri, tetapi selalu dalam kaitan internalnya dengan unsur-unsur yang lain

Untuk menelusuri tanda-tanda dari pemaknaan yang terkandung di dalamnya kita dapat menganalisis elemen-elemen atau figur unsur yang ada dalam karya seni tersebut secara terpisah. Elemen-elemen bentuknya, dapat membantu pemahaman terhadap karya seni lukis. Analisis semacam ini disebut analisis bentuk (formal analysis).

\section{Elemen-elemen Karya Rupa}

Karya seni rupa pada dasarnya merupakan kesatuan organis antara gagasan (isi) dan teknik (bentuk). Dalam teori organis, karya seni dapat dilihat sebagai sistem organik, bukan sebagai sistem mekanik. Pada sistem organik setiap unsur tidak berperan secara terpisah, tetapi selalu dalam kaitan internalnya yang substantif. Analisis pada karya seni rupa didasarkan pada peranan elemen-elemen bentuknya, yang digugah melalui substansi lain, yaitu idea dan subject matter. Elemen-elemen seni rupa tersebut berupa garis, bentuk, volume, gelap terang, tekstur, dan warna. Implementasi figur unsur ini disesuaikan dengan konsepsi dan ekspresi penciptanya.

a. Garis

Garis merupakan coretan panjang (lurus, bengkok, atau lengkung) Garis juga dapat berupa tepi suatu bidang datar, sumbu atau arah dari suatu bentuk (shape), sebagai kontur atau garis lurus suatu benda. Garis dapat bersifat rata dan tebal tipis, garis juga memiliki kemampuan mengungkap gerak, perasaan, kepribadian, nilai, dan aneka makna melalui ungkapanungkapangrafis. Termasuk ilusi visual (plastisitas, kedalaman, keruangan, dan kejauhan, serta tekstur(Sidik, 1979: 10).

\section{b. Bentuk}

Bentuk adalah bidang yang memiliki batas tertentu, dalam artian shape bentuk mempunyai dimensi panjang dan lebar. Sementara itu, bentuk dalam arti form, mengarah pada tiga dimensi yang memiliki volume (massa). Bentuk atau bangun dapat ditinjau sebagai ekspresi atau kepribadian, seperti kaku, luwes, tegas, figur-samar, terang, dinamis, dan aneh.

c. Warna

Warna adalah kesan yang diperoleh mata dari cahaya yang dipantulkan oleh benda-benda yang dikenainya. Warna memiliki peran yang penting dalam seni rupa, karena dengan warna dapat mengungkapkan berbagai maksud dan tujuan yang diinginkan seseorang, sehingga apa yang diinginkan dan dipikirkan dapat terwakili oleh warna tersebut.

\section{d. Volume (massa)}

Volume merupakan kepadatan tiga dimensi yang digunakan secara langsung oleh pematung atau arsitek. Volume juga memiliki keruangan. Dalam seni lukis, volume diciptakan melalui ilusi yang mengesankan keruangan. Penggambaran massa dengan ilusi dapat dibentuk dengan garis- 
garis atau dengan gelap terang (kiaroskuro), massa dapat mengesankan berat, arah, tegar, masif, dan kokoh.

\section{e. Gelap terang}

Gelap terang adalah pemberian kesan-kesan tiga dimensional pada bentuk-bentuk yang akan ditampilkan. Gelap terang merupakan perbedaan yang berkenaan dengan sinar atau cahaya, unsur ini dapat ditampilkan secara kontras atau menyolok, atau sebaliknya dengan peralihan gradual (gradasi). Manipulasi gelap terang dapat memberi kesan soliditas, jarak, tekstur dan bentuk.

\section{f. Tekstur}

Tekstur adalah kualitas nilai raba dari suatu permukaan, yang memiliki sifat-sifat lembut, kasar, licin, lunak atau keras.

\section{PEMBAHASAN}

Bentuk secara keseluruhan dalam karya seni rupa adalah organisasi dari seluruh elemen yang membentuk karya seni rupa. Bentuk adalah penggunaan alatalat visual (visual devices) atau elemen-elemen bentuk berupa garis, bentuk (shape), gelap terang, tekstur dan warna. Penggunaan elemen-elemen bentuk ini menentukan perwujudan karya seni rupa. Disamping itu ada yang disebut isi atau ide yang merupakan gambaran perasaan terhadap suatu nilai yang telah dikembangkan menjadi gambaran yang memiliki potensi teknis untuk dituangkan ke dalam bentuk karya. Isi merupakan tema atau makna yang dikomunikasikan oleh seniman.

Dalam memahami makna karya seni rupa, hendaknya dapat diliha sebagai satu kesatuan yang menyeluruh, antara bentuk dan isi serta ekspresi yang disampaikan. Karya seni merupakan kesatuan organik (organic unity) antar unsurunsurnya. Bentuk dan isi harus sama-sama dilihat sebagai kesatuan organis, bukan sebagai sistem mekanik. Pada sistem organik, setiap unsur-unsur tidak berperan sendiri-sendiri, tetapi selalu dalam kaitan internalnya dengan unsur-unsur yang lain. Akan tetapi, untuk menelusuri tanda-tanda dari pemaknaan yang terkandung di dalamnya kita dapat menganalisa elemen-elemen atau unsur-unsur yang ada dalam karya seni tersebut, seperti garis, warna, bentuk, gelap terang, ruang.

Sehubungan dengan etika, etis, dan estetika dalam seni rupa, difokuskan pada karya-karya yang menampilkan figur manusia telanjang berupa lukisan, patung, dan relief candi. Figur-figur telanjang tersebut berkesan erotis dan sering dihubungkan dengan seksualitas. Erotisme menjadi wacana dalam kesenian karena selalu ada sepanjang kehidupan umat manusia di seluruh dunia, sejak zaman prasejarah sampai kini. Gambaran dan uraian tentang seksualitas selalu muncul. Pada zaman prasejarah gambaran tentang seksualitas tampak pada patung dan relief di gua-gua, yang hampir selalu berkaitan dengan kesuburan, baik kesuburan manusia, sebagai bagian dari survival manusia, maupun kesuburan binatang buruan agar makanan tidak habis.

Erotisme pada masa prasejarah dan pada perkembangan kebudayaan di masa lalu berkaitan dengan kehidupan bersama. Pada masa kini erotisme berkaitan dengan seksualitasnya, yaitu hubungan antara perempuan dan laki-laki, yang cenderung bermakna hubungan seks. Etika, etis, dan estetika saling berkaitan, maka perlu dijaga. Apalagi agama dan adat istiadat di Indonesia sudah ada sejak nenek moyang. Etika berkarya seni harus dihubungkan dengan norma-norma yang berlaku di Indonesia, keculi karya rupa untuk studi atau tujuan-tujuan tertentu. Etis dihubungkan dengan kelayakan logika dan adat istiadat yang berlaku di Indonesia. Sementara itu, estetika berada di wilayah rasa, sehingga sangat relatif bagi setiap individu yang merasakan, maka membicarakan masalah nilai estetika dan erotika di wilayah relativitas tentulah tiada habisnya.

Pihak moderat yang mempercayai bahwa nilai-nilai di masyarakat selalu berubah, biasanya akan dongkol, apabila terus dihambat dengan teori-teori dogmatis. Apalagi jika sudah dikristalkan jadi peraturan, seperti RUU Antipornografi dan Pornoaksi. Sementara penganut teori dogmatik akan bingung (dan semakin pasif), apabila terus dipaksa untuk bergerak dari keyakinannya yang ketinggalan zaman. Kalau diperhatikan di negara-negara maju, karya seni rupa yang mempersoalkan ketelanjangan perempuan (yang lalu ditatap sebagai erotisme, sensualisme, dan seksualisme) mempunyai wilayah yang jelas, yaitu wilayah seni, sehingga diapresiasi oleh kebanyakan yang paham seni. Dengan demikian, nilai-nilainya ditimbang dengan parameter sendiri, yaitu parameter seni. Kalau diperhatikan di Indonesia, sejak dahulu sudah tercipta karya yang erotis, seperti lukisan klasik Bali dan Jawa. Begitu pula patung-patung Irian yang meletakan figur seks, dengan menampilkan phallus sebagai figur ritual. Mungkin kita lebih arif (dan tidak munafik) dalam memosisikan persoalan erotik dan sensualitas dalam masyarakat Indonesia dan menjadi mengerti, mengapa seni rupa erotik Indonesia akan selalu tercipta (Dermawan, 2006: 62).

\section{PENUTUP}

Berdasarkan kajian di atas dapat disimpulkan bahwa unsur-unsur seni rupa adalah sebagai berikut. Pertama, garis lebih berperan sebagai pembentuk kontur objek (outline),membentuk orang, bangunan, pohon, awan, gunung, dan lain-lain. Dalam hal ini, garis berfungsi sebagai pengungkap ide-ide serta menciptakan suasana atau kesan yang ditimbulkannya. Kedua, kecenderungan menggunakan warna campuran, misalnya primer dan sekunder akan memberikan kesan kematangan. Warna-warna tersebut, antara lain merah, kuning, hijau, ungu, 
dan oranye. Ketiga, bentuk gambar cenderung menampilkan figur manusia secara realis. Keempat, komposisi cenderung menampilkan pusat perhatian, sehingga objek dapat terfokus.

Kriteria etika, etis, dan estetika dalam karya seni, khususnya seni rupa sangatlah kompleks. Apalagi kita berada dilingkungan adat istiadat ketimuran yang sangat kental dengan norma-norma/etika sopan santun. Seni di Indonesia memang banyak menampilkan figur-figur erotis, seperti dalam peninggalan reliefrelief pada Candi Prambanan, Borobudur, Candi Sukuh, dan bahkan relief-relief pada goa-goa berupa figur-figur manusia yang dibuat tanpa busana atau setengah telanjang. Karya-karya tersebut dapat ditelaah dari sudut pandang etika, etis, dan estetika di Indonesia. Tentu saja karya-karya tersebut sangat ditentukan oleh sudut pandang kebermanfaatan dan tujuan-tujuan tertentu dari pembuatannya.

Misalnya, ada karya tertentu yang ditujukan untuk studi anatomi atau gambar model. Tentu saja hal ini sangat membutuhkan model langsung, apalagi kalau harus menampilkan karya rupa dengan figur telanjang, baik laki-laki maupun perempuan. Namun demikian, yang harus disadari kita memegang adat ketimuran yang sarat dengan norma-norma kesusilaan dan adat istiadat.

Sejauh ini rasanya belum ada lukisan atau patung dengan pokok karya perempuan telanjang yang dihebohkan publik seni rupa. Masyarakat Indonesia menerimanya sebagai karya seni. Oleh karena itu, sebagian mereka tidak mempermasalahkan ketelanjangan dalam karya seni sebagai pornografi. Barangkali masyarakat seni rupa, bahkan masyarakat pada umumnya, sudah cukup apresiatif melihat karya seni rupa dengan pokok karya figur telanjang atau setengah telanjang. Relief dan patung di candi-candi serta stupa, misalnya menampilkan figur telanjang atau setengah telanjang dan masyarakat tidak mempersoalkan hal tersebut.

\section{DAFTAR PUSTAKA}

Dermawan. T Agus, 2006. Visual Arts, Buana Printing, Jakarta.

Djelantik, A.A. Made, 1985. Seni Lukis Bali Dewasa Ini Dimata Dunia, Perumusan Saresahan Seni, Taman Budaya Denpasar.

Gie, The Liang. 1976. Garis Besar Estetikan (Filsafat Keindahan), Cetakan II, karya, Yogyakarta

Soedarso SP. 1990. Tinjauan Seni. Yogyakarta: Saku Dayar Sana Yogyakarta.

Sidik, Fadjar dan Aming Prayitno. 1979. Disain Elementer, STSRI ASRI, Yogyakarta

Sumardjo, Jakob. 2000, Filsafat Seni, ITB, Bandung.

Sura, I Gede. Agama Hindu. Denpasar: Kayu Mas, 1985 
